\title{
Efficiency of Steam Separators
}

\author{
J. H. Felgar \\ D. E. Willard \\ H. A. Durr
}

1905

621.17

F 33 


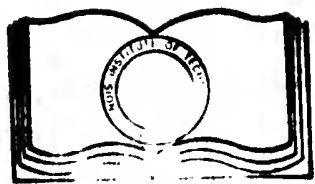

Ilinoiv, mstitute of Technology

Libraries 
AT 8

Felgar, J. H.

Efficiency of steam

separators 


EFFICIENCY CF STEAM SEPARATORS.

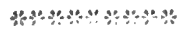

A THESIS PRTEENTED

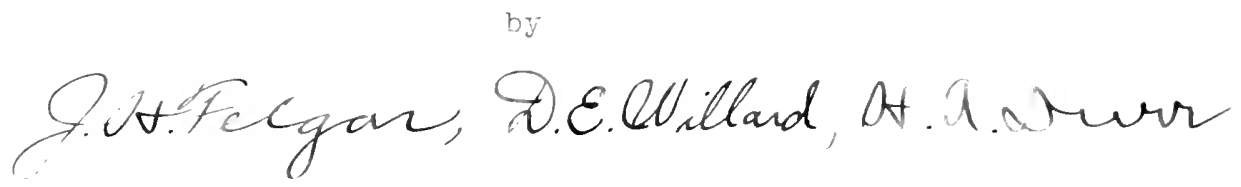

to the

PRESIDENT AND FACULTY

of

ARNOUR INSTITUTE CF TECHNOLOGY

for the degree

or

BACHELOR OF SCIWTCE IN MECHANICAL ENGINEERING,

huving ouploted tro reseribed course of study

$\vdots n$

NECHANICAL ENG INETRING。

ILLINOIS INSTITUTE OF TECHNOLOGY Chi CaEO, JUIE 25, In.5.

PAUUL V GALVIN LISRARY

35 WEST 33RD STREET

CHICAGO, IL 60616

$$
\text { apporded tivel hand }
$$



Tho objuct of this thosis wh to detornine the officiency of horizontal ond a vertical ccorrator o: tho baffle plute tyne uncior the varying oonditions of gulity with the valocity constant, and also under the veruing conditions of velonity uth quality constant. 


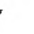




\section{The Wriciency or letem Eenarators.}

The separitoris mre alrendy in place as doscribod below, with esch scyarator and the connecting pines rell lagged. It was nocewsiry however to arrongo apparatus to tcke care of certatin conm ations. (z) Sone method of obtaining the desired quality of stean. (a) Somo way of taking care of the water sonambed so as to deternine its woight accuratoly. (5) Neans by which tho volooity could be changed at rill, as the moximum velocity with tho ongine ruming wa only sbout 1000 reot per minute. (A) The accuracy of the calorineters.

First, the hicher qualities wore obtained by the uso of two coils inserted in the unlaggod joints of kl pipe, 7ith water pumped throligh them at different pressures. For lomor qualitics a nozale ws used and tho water pumped diroctry into tho stedm linf. A conbination of thesc twn methods was used for the lowest qualilies.

Second, the anount of rater separnted was pirst mensured by weighing, it, but a lorge orrop was introduced here on account of tho water under a reduced pressure prasing into stear, and also by tho watur splashing over tho sidos of tho woighing con. Theso diricultios ware overcome by attaching to No. I separnor an additional charber with a gruge glass calibrated to rend to huncroduch of a pound at stear temorature tho quantity of vater sop-rated, 
and the ganco olass of no. 2 was cal ibrated.

Third, with the ongine ruming at full load, the velocity of the steam ws about 1000 reet per minute. To obtain groater velocity tho steam and exhaust valves in the hich prossure cylinder woro romovod, the lower pressure cylinder by-passod, nht tho stom alIomed to pass directly to the condenser. Any velocily coukd be obtained by tinis nethod.

Fourth, in opuer to got some basis from wich to conpute the gualities, the throttling calorimeter mes taken as conrcot, results chocking very satispactorily with tho separcting calorineter.

In the norizontal soparntor tho corrugated bafple plato utonds vortically, and at richt angles to the direction of the frov of the staan; the stewn striking this ninto and losine ito ontrained motor, passes over tho top of the barrlo plate, and on to the engine. The water drops by gravity into the chember bolow. 
. 
In the vertical separator the stean enters from the top, strikes in oblique corrurgted bafrle plate, and passes to the engine throu an opening directly undor this baffle. Drawings of crose section of the soparators cre apponated.

These separators are connected to the steam of a cross compound corliss engine. The tate-off from the steam header corsists of two sections of unjagged $4^{\prime \prime}$ pipe, $\underline{Z}$ and $\underline{x}$, which load into another linc of $A^{\prime \prime}$ pipe $\underline{Y}$; at the miclde of this is the horiztonel separator No. 1. In this same lino, just above tho throttle valve of the engine, is the vertical separator No.?. Below the separator 1.0 .1 is the reservoir No. F, With the gauge glass and a scalo Eraduated to read to hundredths of a pound. There is also a greduited scale on separetor No. ?.

A separating calorimetor $(A)$ is in the stoam lino imeciat Iy belore the sopamtor wo. I. Jibovise a seperating calorimetor (E) is between soparntors No. I and No. ?. A throtiting of crimoter :e uI:ced arter the separator No.?, and before the throttle valve.

The stoam Gauec (D) is placed at th thrott?o; a vacuum gauce (i) on the condonser; 3 water prosure gruge (F) on the wator

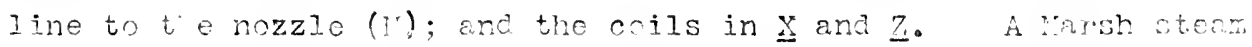
pump is shom at ( $G$ ) which is asce wo force weter into the man stem line to decresse the gu-lity. Drain pipes are shom nt

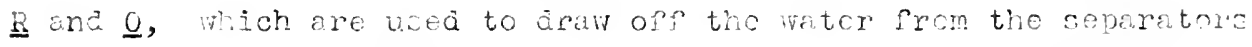
No. I and iro. ?, resnectively, into a pit between the nis'? and iom pressure cylinders. In order to ootain wat stoars an a f. longth

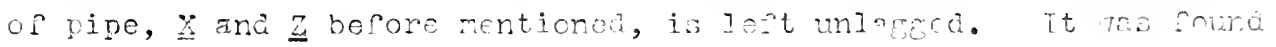


that this unlagied sociton, topothor with s wher coolnd conpor coil in the "ipe n, wa not suriciont to givo "ho

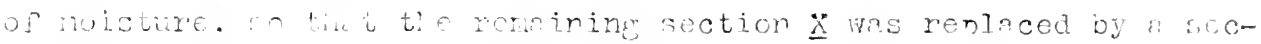
tion containing, a wer coupa iron nil. with these tro coilas and a 40-10. Woter prossure a quality of onjy cos could ke ohtainea. This stean did not contain sufpioiont moloture, so somo other means had to be dovised to obtain wottor stcam. This was done by insfrting a T/M" pipe into the stear line just before the copper coij. A cap in wibch cigte $7 / 3$ " holes were drilled recially wes corved on the ond of this 1/4" pipe. This nozzle mas placed at the center of the stean pine, In order to force mater through this nozzlo against stearn pressure a small irash pump, shown at G, was used.

It was round that precticaliy any desired quelity of steam could be obtaineu by using tho nozzle and cooling coils combined, but the bad feoture here wa that with low quality the separating colorineter did not seer to read corrently. This ins readizy expleined, for the samping pine connected wit: the separating calorineter w $s$ ituratoa in the center of the $4 "$ stoam Iine, wrid therefore shomed tho guality of tho steam at that ront, but with these 707 gur? itios so much water flowed through the Dipe that the water wa not thorowhily rixod with the stear, and a part on it ran alone the bottom on the secam line. A differat

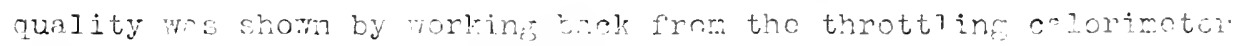
rocairge taken at the oneine propor. It vas ascumad thet the latter method vos the fairer and for thet remon the initien juelities of the sterm were all colculated from tho thrott? ing color- 

Lweter realing and considored to be correct. other nozzlca riti smaler holas wore triej to give the water ontoring on inore-sed velocity, but on checring tho qualities shom by the ca? orimeter. with the culculnted qunity the sane remlt was obtained. aith a volocity of 1000 foet per minute the echerating calorineter weula not show a quality lower than or\%.

It was round thet ith the 40 pound water nrossure ne the Institute rins a surficiont amount of water would not pass through the coils. It istiorelore nocosseny to inorense the pressure to 100 los. pr square incl. A quality as low as $9 \% \%$ wo obtainca with both coizs and a velocily of stoam of 1000 feet, and uth one coil a quality of ar.. "With roth coils a nozalo having seven wo. crillea oles and a velocity of steam of noco fect ner minute, a quality of $4: .5 \%$ wos obtaincd, and under the same conditione, ith a velocity of 5000 feet ner minute a quality nf $60 .+$ ws obtaind. 


\section{Desclintion of the Conditicns for bach of the Rune. (pererence made to rentit greots.)}

Shout wo. 1, : 8 y 5,1005 .

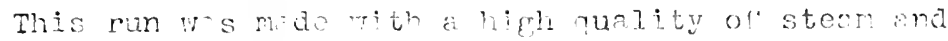
noither the nozle nor orile were used. The engine was runring under full load, and a steam velocity of 889 feot ner ininute wrs obtained. The initial runity of the stean for sepreator No. I ws $95.9 \%$ and the qualily after screrntion wh $97.7 \%$, Eiving an etficiency of no. The initin? runlity of separator

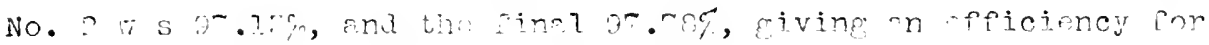

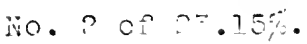

shoet fio. n, Nay 5 , lins.

In this run the corper coil ws necd with a 10 nound

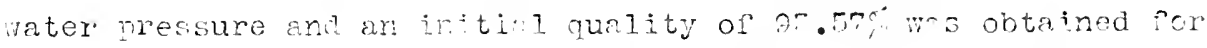

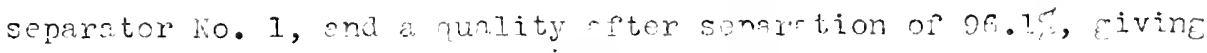
an efficiency for Ho. 1 or $6.7 \%$. For Ho. n Lhere was an initivi quality of as.l, and a quality after ceparation of n. The, fivine an officiency of ty. fr. The velooity thrnu'h the nipe wes $9 \supseteq 0$ lett per minute.

shoet ro., hay loth, 1005 .

Woth coils wore used in this mu under a 40 -oound woter pressure, giving an initial gunlity of 8\%.9\% for seneretor No. ?, Wi'h a quelity of 05 . af after seremetion and an efficiency of

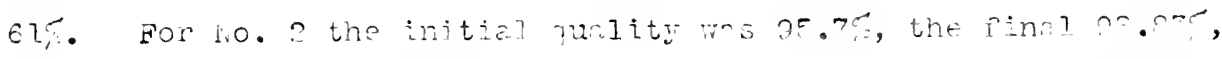

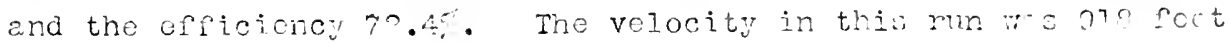
per minute. 

Sheet No. A, iray $18,1305$.

In tice time betwoen the run sheet No. " and this run, thenozzle had been insorted and trial runs made as describod clsowhore and the two coils hid :lso been rrranged so thet wntor could be pumped through then by mons of the Varsh pump. In order to get a higher velocity the valves in the hend end of the high prossure oylindor had boen rowoved, the steam boing allowed to poss diverty to the condens r. This run $w$ made with a l"rgo nozzlc only, and a steam velocity of sloo foct per minute. The initial qunity was $\mathrm{ne}$. for No. 1 , with a final qurlity of $=7 . "$, giving on officioncy of 75 . The initial qunlity for Mo. $n$ wh 27.\%, and the quality arter seporetion 4 on, giving an enicien?y oI 16.000 .

iith a stean velocity of 5755 feet per minute, on initial qurlity of $50.0 \%$ for iNo. I was obtained, a fincl quality of $77.4 \%$, givine an creiciency or $A z .7 \%$, while for lio.? the initial quality

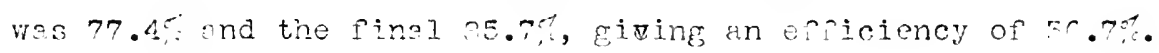

Sheet ino. 5, liay 19, 1005, 11:-5 A.?.

This was o run with comper tively dry steam and a hich velocity (6910 feot ner ninute) and neither the nozzlencr coils were used. The initial quality ws $9^{\circ} .84 \%$ for ro. I, the final

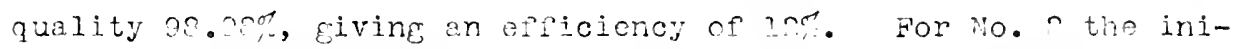

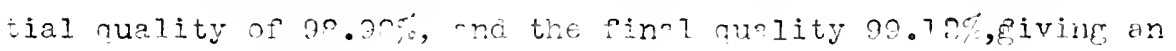
êficiency of $1=\%$. 

sho t No. E, Yay 10, 1005, 1::05 $\Gamma \ldots$.

water wo numper through both coils wiving an initiel qunlity or 91 . O\% ror a velority or the store nt roso rote nor ninute. The queity cetor ho. 1 was 97 . for, and thefeizjency

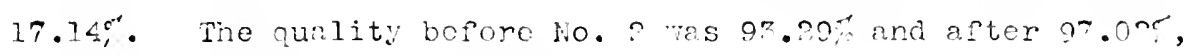
giving an cficiency of $70.5 \%$

Sheet No. 7, May 10, 1905, ? P.ï.

In this aun the wher was pumpea throurh the iron coil crly, and the velocity of the sterm ws 4 ra fo fot per minute. The quality before No. 1 was $91.54 \%$, aftor, ws $34.75 \%$, giving an officienoy of $87.36 \%$. Whe quality of the steam ontoring lio. ? \#s 94.7\%, laaving was no. of, giving an efficienoy of $70.1 \%$.

Sheet No. $\%$, MY 19, 1005, 2:55 P.X.

iater was pumpe thrnugh bouh coins; and the steam velocity $=910$ feet per minute. The quelity of the steam entoring No. 1 ws n. OF, loaving on. 1\%, giving an erpiciency of $4.0 \%$

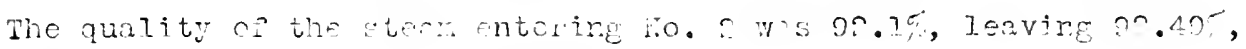
Giving an eticiency of on. ?5:

Sheot. io. 0, Hey $17,1705$.

In this min the cngino was onfrated under ful? lond are the rater wis pumpod throurh the coils. The steam velocity ".; 1660 foot por rinuto. The funity of the steam enterirg lio. 1 ,

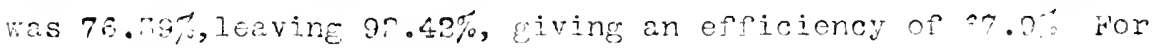

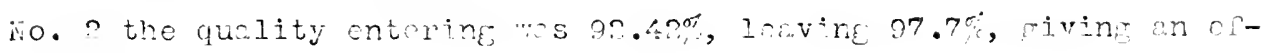
ficiency of $60.5 \%$ 
. 
Shot 10 , ray $12,1005,5: 45$ T.M.

In this run the water was numped through both coils, the stear velocity was nes feet per ninute, and the valves were removed from the enfine as in theother runs or this dete. The steam entering No. I had a quality of $89.7 \%$, loaving, $91 \%$, Elving an efficiency of $40 . \mathrm{fm}$. The steam ontering No. ?had 8 quality of 91, lervine on.nar, giving an efficiency of on. Ler.

Sheot iNo. Il, liay 19, lno. 4: 5 . P.i.

.rater wh pundend througk the iron coil cnly. The steam had \& velocity of $\cong .70$ feet per minute. Tho qualit: of steam entering No. I was $77.0 \%$, leaving $97.7 \%$, giving an orsiciency of $13.57 \%$. The quelit; of the steam entering No. ? was $97.7 \%$, loaving $90.50 \%$, fiving an efficiency of $7 \% .45$.

It must be noted thet the qualities iven by calorimetnr No. I for hay 19, 1905, are unresonable, beceuse the carorinetr $r$ indicated a poorer quality than that calculated fror the actual woichts of entrained weter in the steam. It is therefore obvious that separating calorimeter (A) ws at Fullt. The orifice ass probably obstructed, causing most of the stem that entered the calorimeter to condense. 


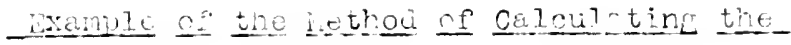 \\ Results.}

Calculotions:

$$
\begin{aligned}
& \text { Tuality of steam oftor sonerator } " 17 \text {. } \\
& \text { cuolity }=\frac{w}{\pi+w}
\end{aligned}
$$

where $w=$ wei $\}^{h}$ t of wher in senarnting colorimeter,

$w$ - wight of condensod stean irom the calorimet'r.

$$
\frac{0.01}{.108+3.01}=\frac{7.01}{-.710}=97.09
$$

Quality of steam according, to throttling calorineter readings.

$$
x=\frac{\lambda-a_{1}+.43 D}{x_{1}} \times 1.00
$$

where $x=$ quality

$$
\begin{aligned}
& \lambda=\text { total heat ol steam at calorimeter pressure, } \\
& q_{1}=\text { heat of Iiquid at stcam pressure, } \\
& r_{1}=\text { Intent heet " " } \\
& D=\text { suncrhost in degree F. } \\
& .43=\text { specific hot of stoam. }
\end{aligned}
$$

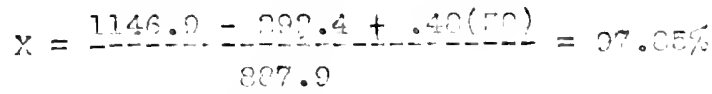

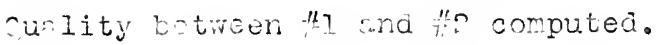

$$
167=\text { luentity of concionsed steam in ter rinutes, }
$$

$167 \times 97.85=167.4$ dry stcar,

$267+2.00$ (moisture from $i^{110}$ in 10 minutes) $=160.07$.

$165.4 \div 263.00=.066=36.6 \%$

$159.09+1.56$ (moisture rrom $z^{\prime \prime} 1$ in 70 min.) - 100.8

$165.4+170.45=.95=00 \%=$ initinl suality. 

-picichcies:

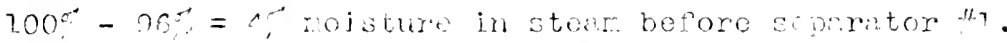

$$
\begin{aligned}
& 37.7-97=7.7 \% \text { proent soproded. } \\
& 1.12+4 \times 100=n 0.2 \% \text { eff. of } " 1 . \\
& 100-37.17=2.97 \text { moisture before t"? } \\
& 97.00-97.7 \%=.7 \% \text { icparated }
\end{aligned}
$$

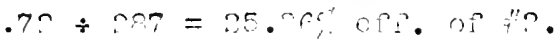

In the above calculations the quelity before aparing H] was oft and aftor $97.7 \cdots \%$

Then qu lity before soparetor to was 97.770 , and after mas $37 \cdot \operatorname{ros}^{2}$ 


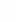




\section{Conc?usions.}

\section{Senarator No. 1.}

(a). Considering runs with practically a constant qua? ity, it is found that the efriciency decreases as the velocity increnses. This may bo due to the fact that the steam of high velnoity unn not derosit the wator on the barfle, but drivos it through the opening at tho top of the senarntor.

(b) Considering runs with constant volocity, it is found that the eniciency increrses as the quality docrenses.

\section{Separator No. 2 .}

(a) The officiency of senarator th is rractically constant for all velocities tith a possiblo maximum efficioncy ct cbout 4000 ft. yer min. The point shom on the curve whose nbscissac is 7000 ft. ner min. would epproech the curve if the quality were tho same so the othor nints plotted.

(b) The efficiency increses very rapidy as the quality decrenses, or as the porcent noisture increnses.

Comprison of scvaritors No. I and Iio. 20

For the sare qualities sonaraior the shome a highor ofpiciency than t? for ny velocity 
- 

$k$

$x^{x}$

$\infty$

$N E$

$N$

$a$ 


$$
n-
$$




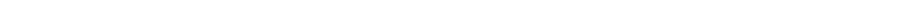


$\checkmark$ 
1 




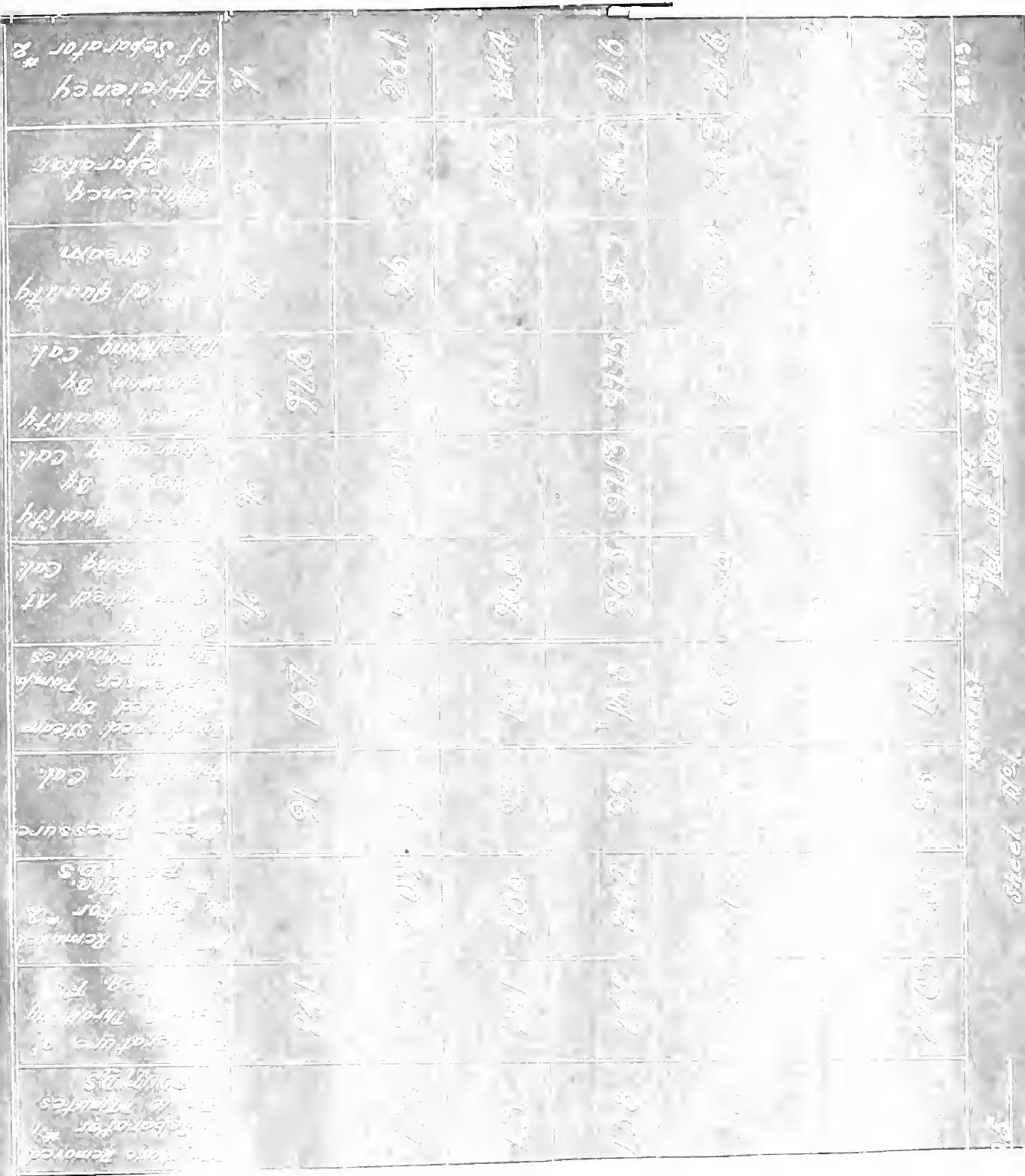




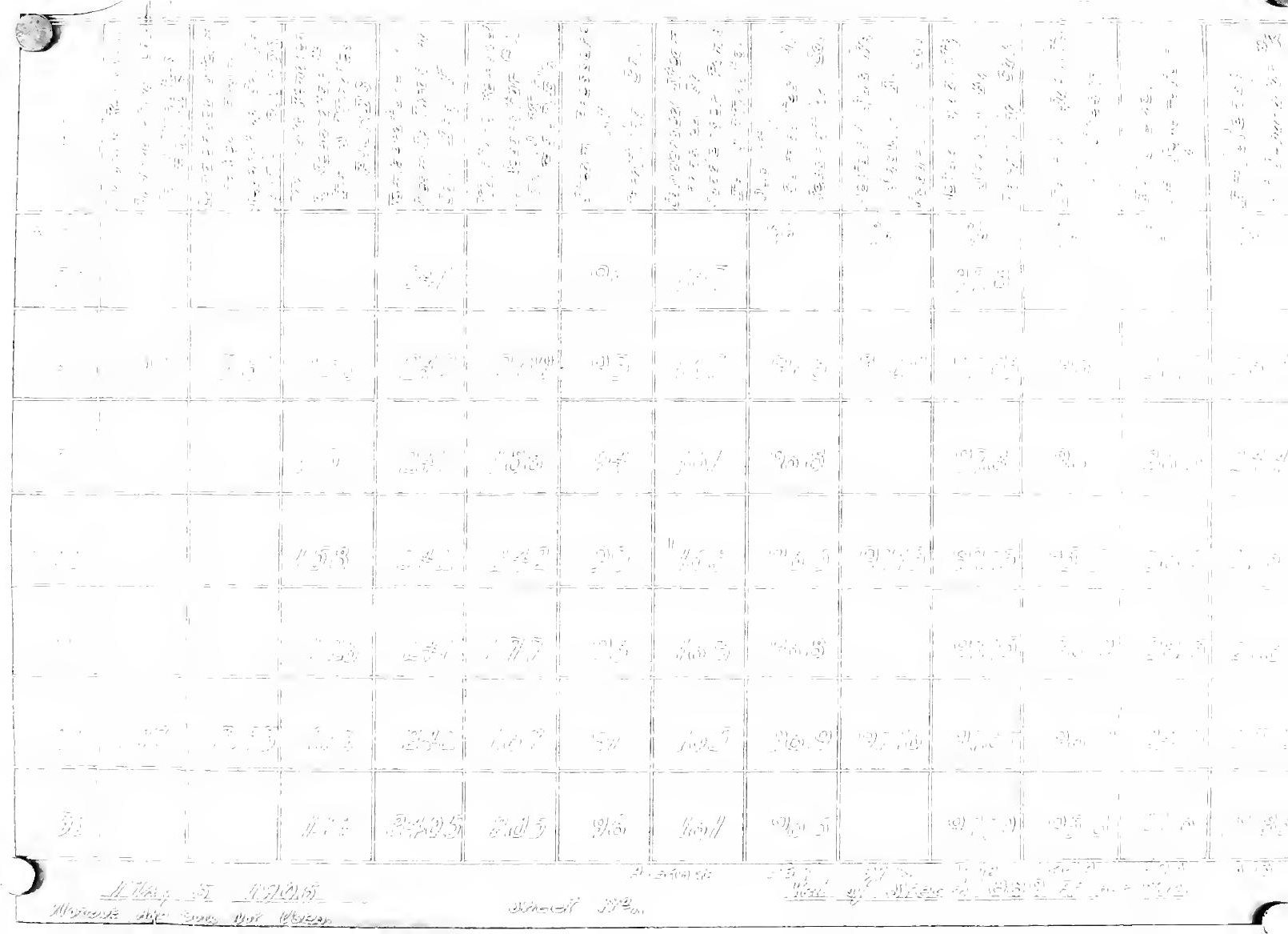




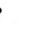




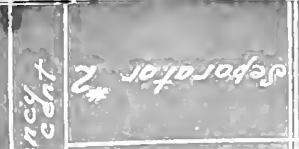
20

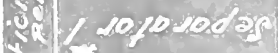
Ni

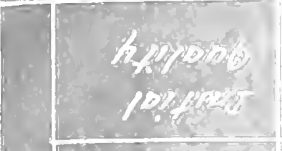

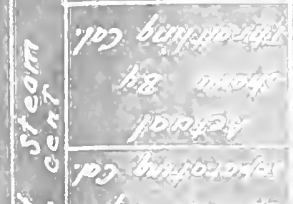
So $A 2$

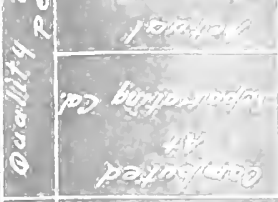
\begin{tabular}{c|c}
0 \\
8 \\
8
\end{tabular}
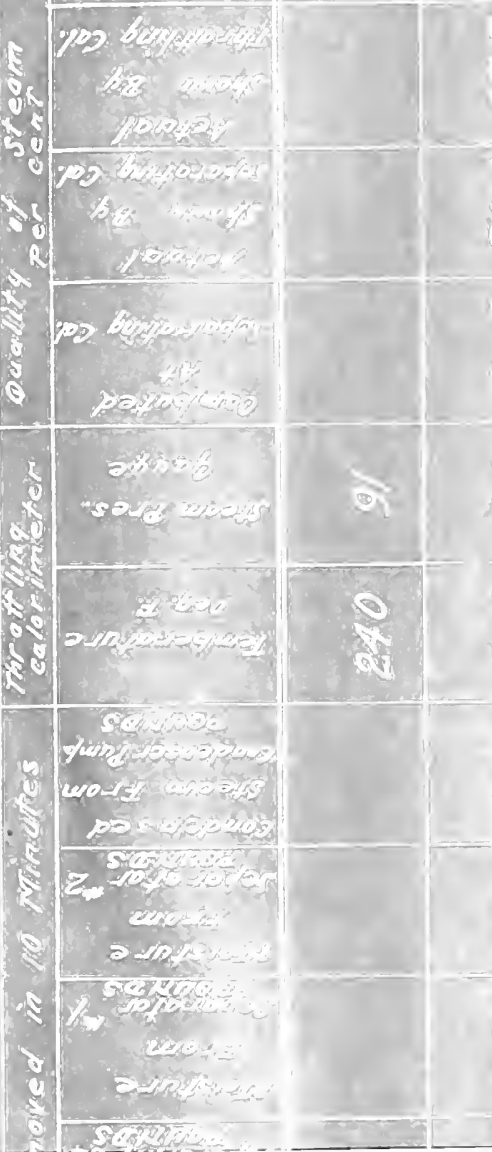

Av कi

in
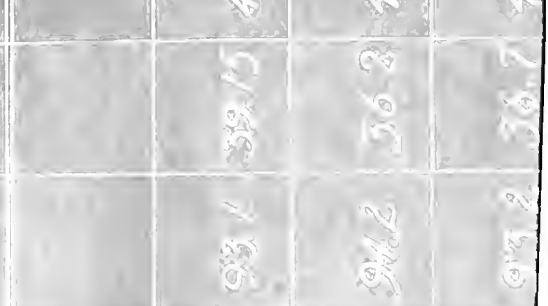

if
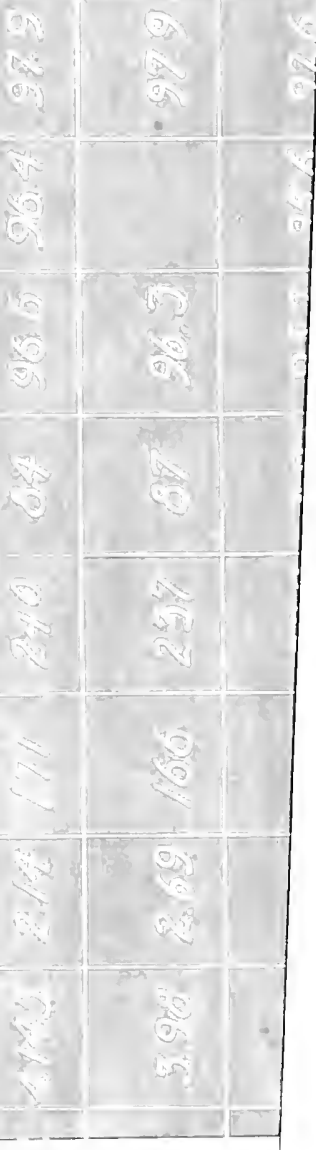


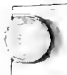

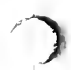





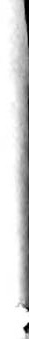


0

$?$

$\curvearrowleft$

r 
$\cdot$ 


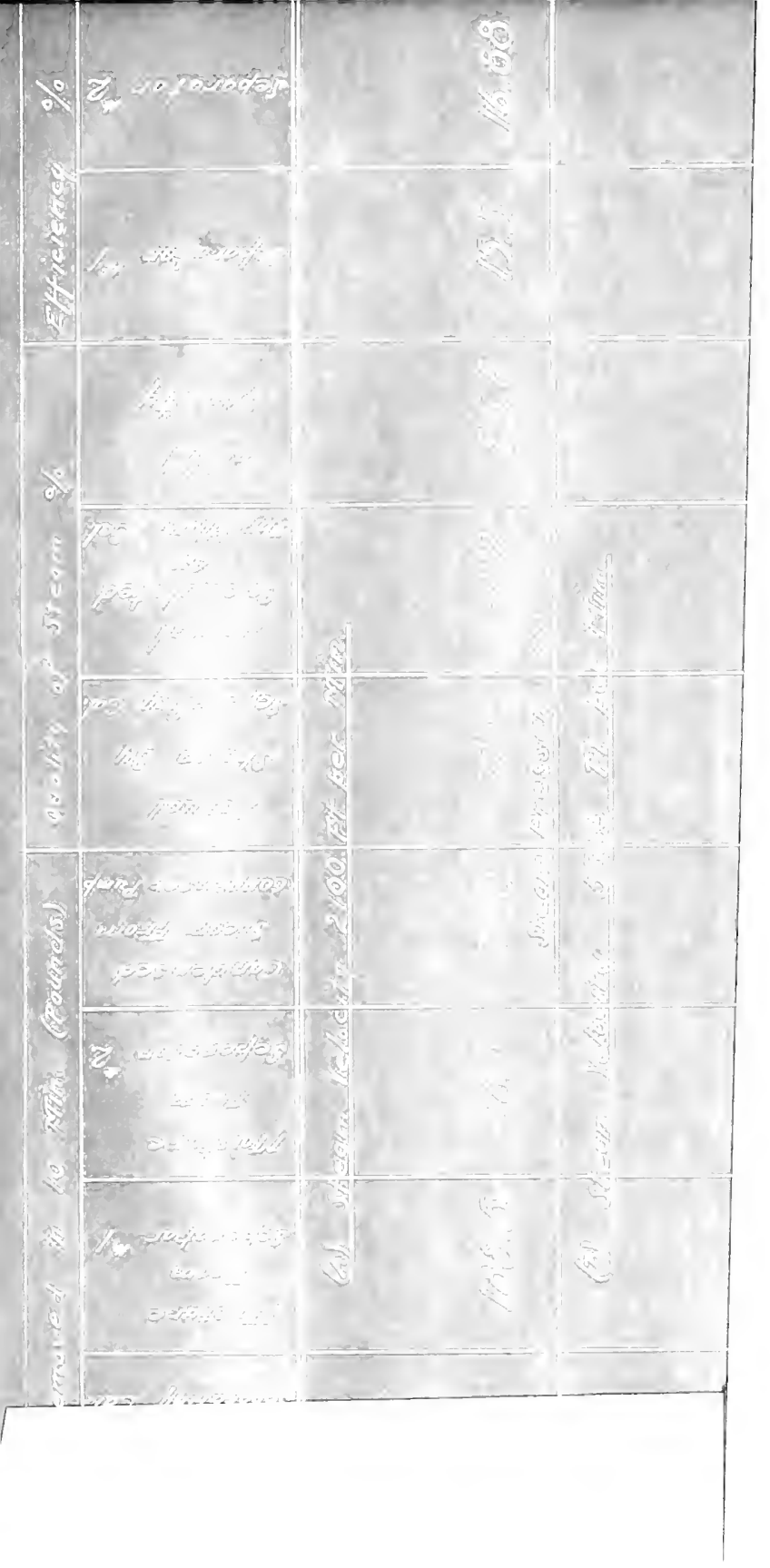



0

$n$
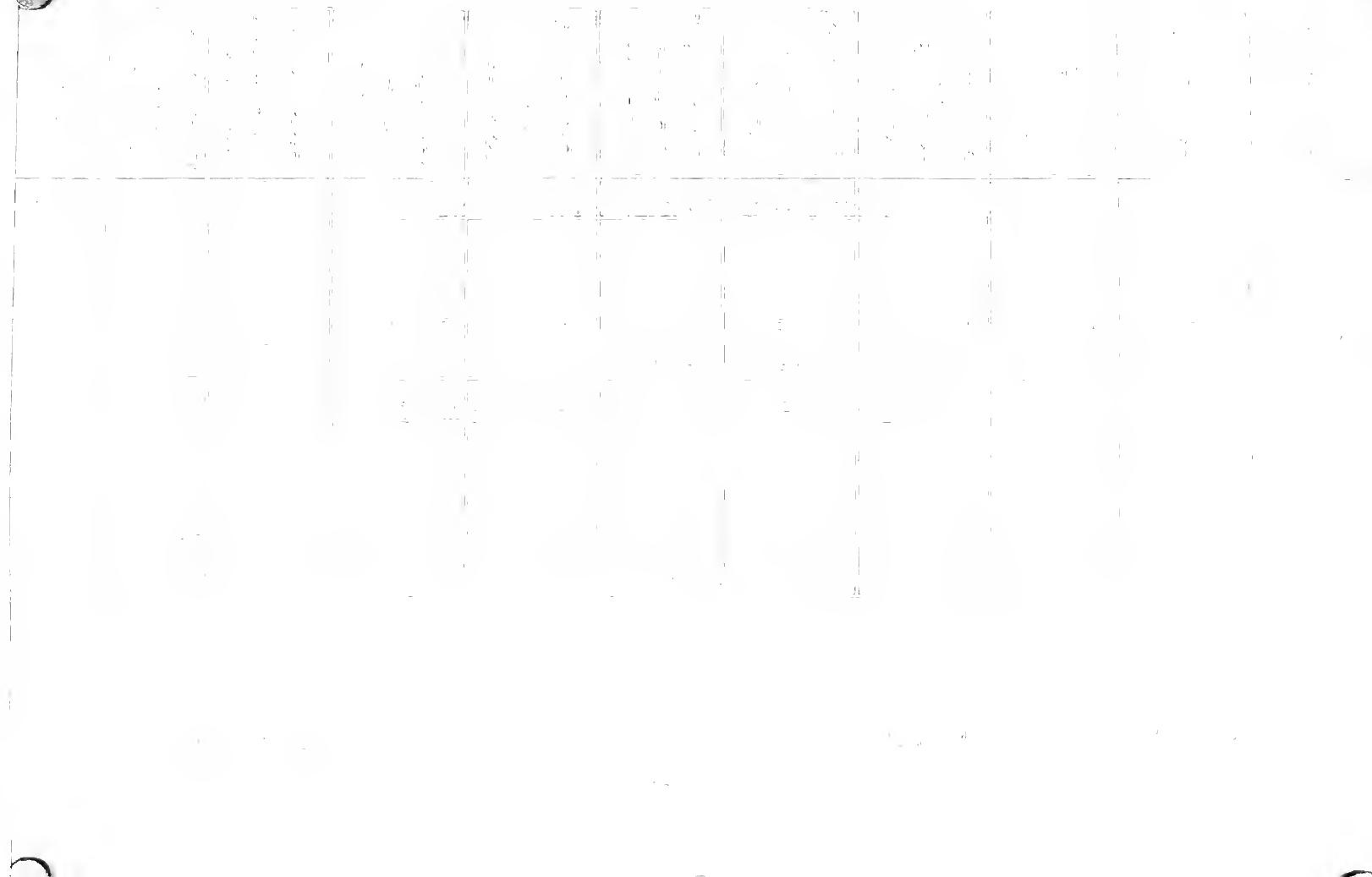

सe

(a)

s.

$3+$
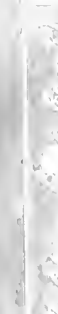

1)

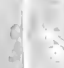

15

18

F5

in
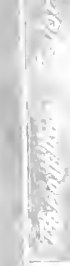

a

(n)

$\therefore 2$
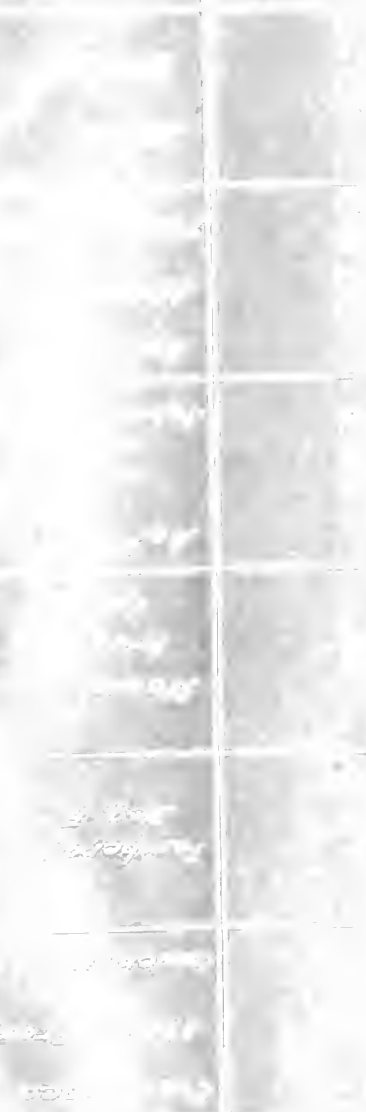

18

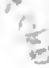



0 



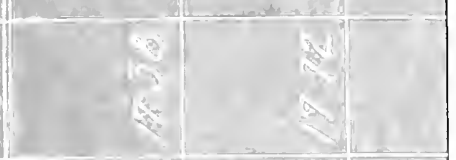

(a.s.

ลี.

Q.

(8)
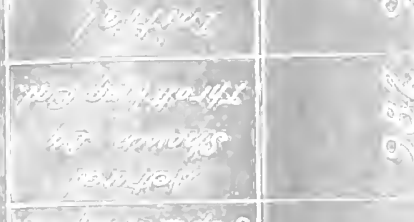

sit
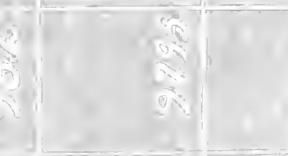

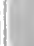



5

$\ln$ 



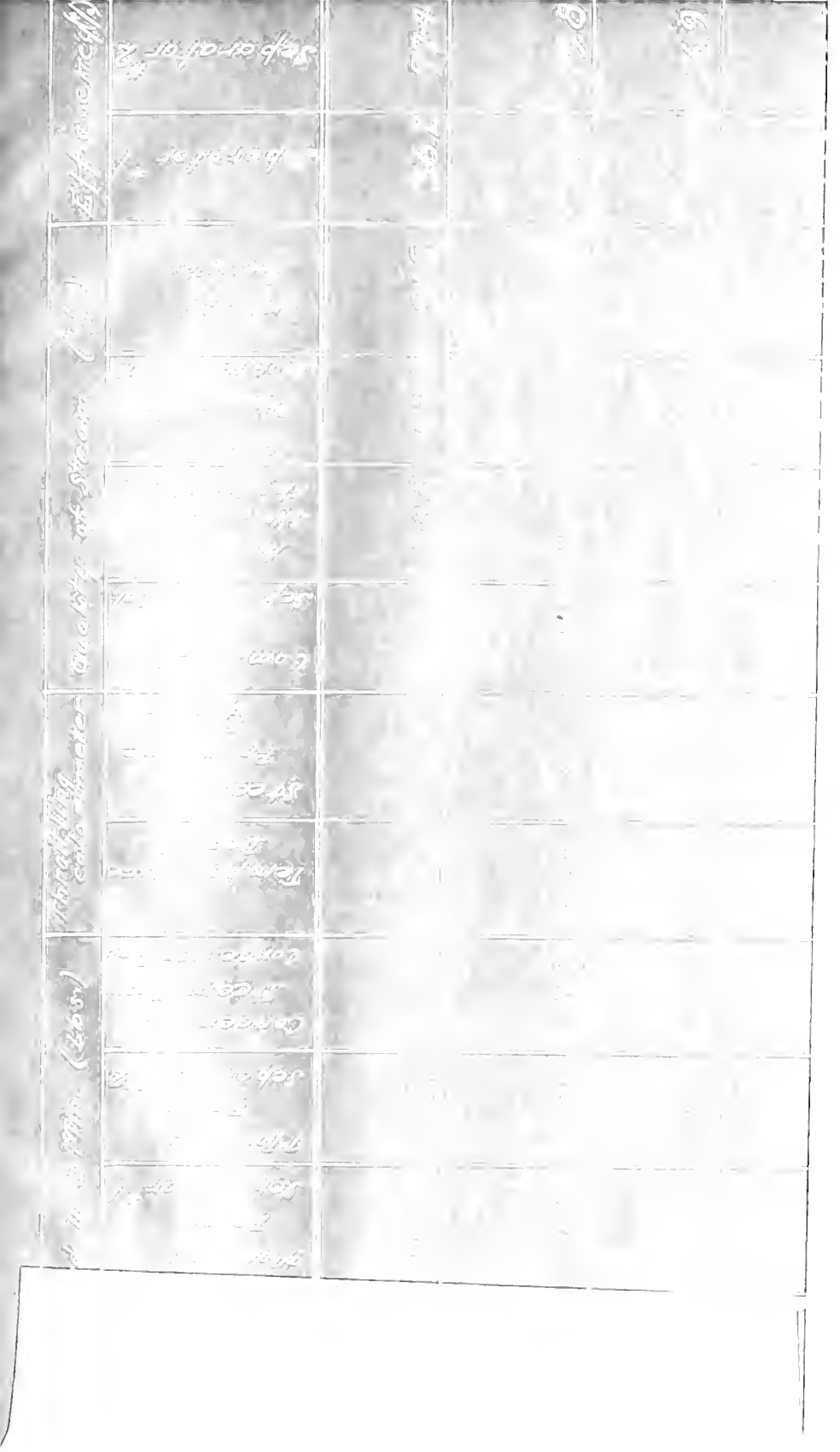



6

$\infty$

7
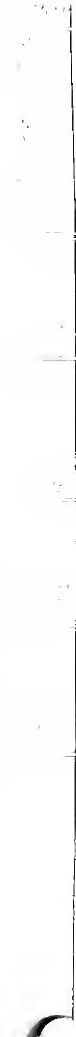



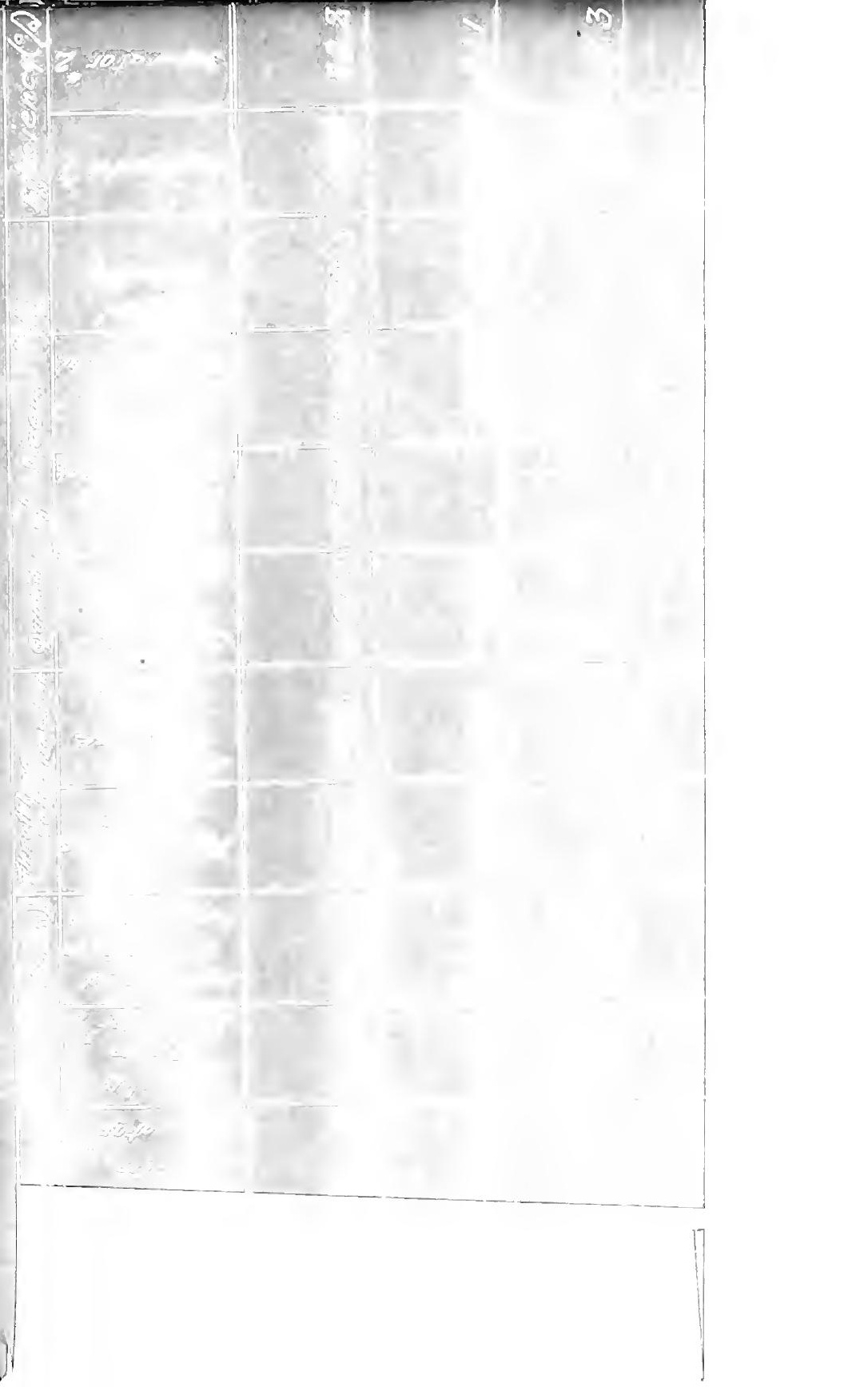



<smiles>C1CCCCC1</smiles> 




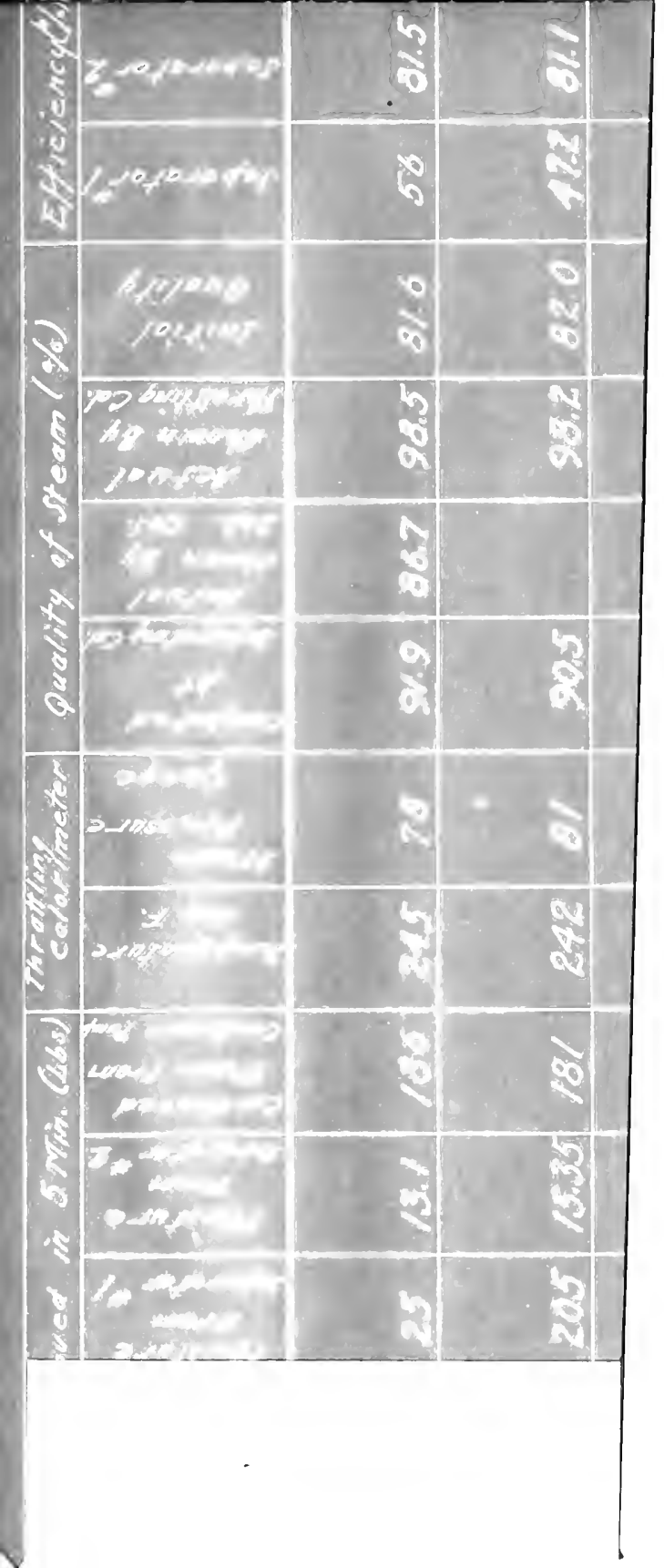





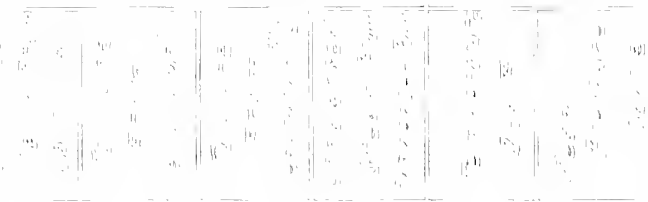

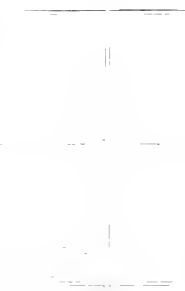

5

3
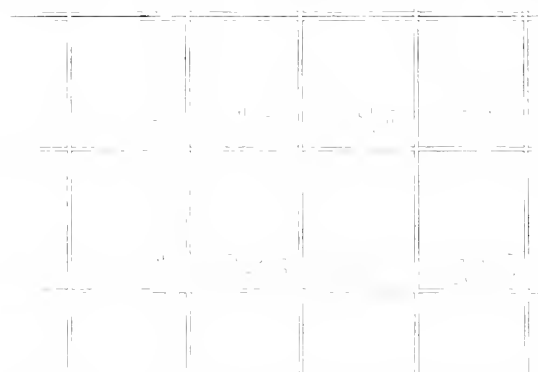




$$
\text { . }
$$



